Interactive comment on "The role of frost cracking in local denudation of steep Alpine headwalls over millennia (Mt. Eiger, Switzerland)" by David Mair et al.

\title{
David Mair et al.
}

david.mair@geo.unibe.ch

Received and published: 14 February 2020

We are grateful for the very constructive review provided by Anonymous Referee \#1. Please find enclosed our response, where comments of the reviewer are colored.

Please also note the supplement to this comment:

https://www.earth-surf-dynam-discuss.net/esurf-2019-56/esurf-2019-56-AC1supplement.pdf

Interactive comment on Earth Surf. Dynam. Discuss., https://doi.org/10.5194/esurf-2019-56, 2019. 